\title{
Clearing of the kidney disease bacterium Renibacterium salmoninarum from seawater by the blue mussel Mytilus edulis, and the status of the mussel as a reservoir of the bacterium
}

\author{
J. O. Paclibare ${ }^{1}$, T. P. T. Evelyn ${ }^{2}$, L. J. Albright ${ }^{1}$, L. Prosperi-Porta ${ }^{2}$ \\ ${ }^{1}$ Institute for Aquaculture Research, Simon Fraser University, Burnaby, British Columbia, Canada V5A 2 Z6 \\ ${ }^{2}$ Department of Fisheries and Oceans, Biological Sciences Branch, Pacific Biological Station, Nanaimo, British Columbia, \\ Canada V9R 5K6
}

\begin{abstract}
The blue mussel Mytilus edulis commonly fouls netpens on salmonid farms along the British Columbia coast, Canada, and salmon farmers have expressed concerns that this bivalve may serve as a source of infectious agents for penned salmonids. The chief concern was that the mussel might concentrate the bacterial kidney disease agent Renibacterium salmoninarum (Rs) from the water column (into which it is shed with the feces of infected salmon) and then serve as a continuous source of infections with this important salmonid pathogen. Our results showed that the mussel is capable of rapidly clearing seawater of suspended Rs cells. In the process, most or all of the ingested Rs cells were killed by the mussel. The bactericidal effect most likely occurred in the mussel's digestive tract, where Rs cells would have been exposed to the lethal substances present in the digestive gland tissues of the mussel. A small portion of viable Rs cells found in the sedimented mussels' feces likely represented Rs cells removed from the water column by the feces during settling. Mussels that were exposed to Rs appeared to free themselves of Rs quite rapidly after they were removed from the Rs-containing water. Thus, although mussels may cause problems for salmon farmers as a result of netpen fouling, it is unlikely that they serve as long-term reservoirs of Rs. In fact, mussels should have the beneficial effect of reducing Rs levels in the netpen environment and thus probably play a role in reducing the frequency of horizontal Rs infections.
\end{abstract}

KEY WORDS: Blue mussel $\cdot$ Mytilus edulis $\cdot$ Reservoir - Bacterial kidney disease $\cdot$ Renibacterium salmoninarum

\section{INTRODUCTION}

Salmon farmers in British Columbia (B.C.), Canada, consider the blue mussel Mytilus edulis a nuisance because it fouls their floats and netpens, adding unwanted weight (and strain) to these structures and reducing water exchange in the pens. The end result is that the nets on the pens must be changed periodically so that they can be freed of the mussels, a tedious and costly process that also imposes stress on the salmon in the netpens.

The salmon farmers also expressed the concern that the mussel, by virtue of its filter-feeding behavior, might concentrate salmonid pathogens present in seawater and then serve as a continuing source of infection with these pathogens on their farms. The farmers were particularly concerned that the mussels might serve as a reservoir for Renibacterium salmoninarum (Rs), the causative agent of bacterial kidney disease (BKD). The bacterium is shed into the water with the feces of salmon with overt BKD (Evelyn unpubl. data). The concern was valid because BKD is the most important disease affecting salmon farmed in seawater in B.C. and because there are no truly effective methods yet available for controlling the disease (Evelyn 1988, Elliott et al. 1989). Further, marine bivalve mollusks had already been reported to serve as reservoirs of certain finfish pathogens (Meyers 1984).

In view of the foregoing concerns, we undertook small-scale laboratory experiments to investigate whether the mussel is likely to serve as a reservoir of Rs on salmon farms. This report presents our findings on this question. 


\section{MATERIALS AND METHODS}

An injtial experiment was carried out to determine whether mussels concentrated and retained Rs cells following exposure to the cells in seawater. This was followed by 2 experiments to assess the mussel's ability to clear seawater of Rs cells and to determine whether the clearing process was bactericidal for Rs. Finally, 2 experiments were conducted to determine whether the digestive tract and its associated digestive gland tissue contained substances lethal for Rs.

Experimental animals and Rs cultures. The mussels used in these experiments were obtained from the intertidal zone in Departure Bay, Nanaimo, B.C., and swab samples of their tissues (gills, mantle, and gut) proved negative for Rs by culture, by the indirect immunofluorescent antibody technique (IFAT; Bullock \& Stuckey 1975), or by Gram stain. The Rs isolate used in the sludies (\#384) was a strain typical of the kidney disease agent (Evelyn et al. 1989) and its virulence had been maintained by periodic passage through salmonids. For use in the experiments, Rs cells were grown to the logarithmic phase on kidney disease medium no. 2 (KDM2) or on selective kidney disease medium (SKDM) (Austin et al. 1983) at $15^{\circ} \mathrm{C}$ and then suspended to the desired concentration in saline $(0.85 \% \mathrm{w} / \mathrm{v} \mathrm{NaCl})$ or in peptone $(0.1 \% \mathrm{w} / \mathrm{v})$-saline (P-S) (as described below).

Enumeration of viable Rs. Counts of viable Rs cells were carried out on SKDM or on KDM2 (Evelyn 1971). The former medium was used when the samples to be counted were likely to contain fast-growing bacteria in addition to Rs. The method used was that of Evelyn et al. (1989) except that a nurse culture was not used. Briefly, the sample to be counted was thoroughly homogenized and then serially diluted in 10-fold steps in cold, sterile P-S. Eight replicate $25 \mu$ drops of the various dilutions were then drop-inoculated on the surface of the agar plates (1 plate dilution ${ }^{-1}$ ). Following imbibition of the liquid in the samples by the agar, the plates were sealed in plastic bags to prevent desiccation, inverted, and incubated at $15^{\circ} \mathrm{C}$ for at least $6 \mathrm{wk}$.

Uptake and retention of Rs cells by mussels. Blue mussels (240 specimens; mean weight $3.7 \mathrm{~g}$ ) were placed in a tank containing $10 \mathrm{I}$ of aerated Departure Bay seawater $\left(25 \%, 15^{\circ} \mathrm{C}\right)$ to which Rs cells had been added to a final concentration of $5 \times 10^{6}$ viable cells $\mathrm{ml}^{-1}$. After $20 \mathrm{~h}$ of exposure, the mussels were removed from the Rs cell suspension and rinsed for several minutes in flowing seawater. At this stage, 20 mussels were sacrificed to provide a time 0 sample and the remainder were placed in a net which was suspended in $15^{\circ} \mathrm{C}$ seawater in Departure Bay. Samples of mussels (20 ind. sample ${ }^{-1}$ ) were then collected at intervals of $1,3,5,7,9,11,24,48,72,96$, and $120 \mathrm{~h}$. Smears and histological sections of mantle, gills, and digestive tract from each animal were then examined for the presence of Rs by the Gram-stain technique. Tissues for the histological tests were fixed in Davidson's fixative and processed into $5 \mu \mathrm{m}$ thick sections by routine methods (Humason 1979). The histological sections were Gram stained by the method of Brown \& Hopps (1973) for the presumptive identification of Rs.

Clearing of Rs cells from seawater by the mussel. In the first of 2 clearing experiments, Rs cells were harvested from the surface of SKDM agar with $9.5 \mathrm{ml}$ of $\mathrm{P}-\mathrm{S}$. The resulting suspension, which had a calculated absorbance of 56.0 at $420 \mathrm{~nm}$, was added to autoclaved seawater to make $4 \mathrm{l}$ of suspension. The concentration of viable Rs cells in the suspension was then determined. The Rs suspension was then divided into 2 equal portions which were dispensed into separate, foil-covered, sterile beakers and aerated with sterile air. The test beaker contained 14 mussels (total weight $100.2 \mathrm{~g}$ ) suspended in a net; the control beaker contained a net but no mussels. Samples $(10 \mathrm{ml})$ of each suspension were removed after $2,24,48,96,120,144$, 168,192 , and $216 \mathrm{~h}$ of incubation at $17.6^{\circ} \mathrm{C}$. The samples were then assayed on SKDM for their content of viable Rs cells.

In the second clearing experiment, Rs cells were harvested from KDM2 in P-S to yield a suspension with a calculated absorbance of 25.8 at 420 nm. The suspension $(8.5 \mathrm{ml})$ was then added to 31 of autoclaved seawater $(25 \%)$ to which $0.1 \%(\mathrm{w} / \mathrm{v})$ peptone had been added to reduce the bactericidal effect of seawater for Rs. The suspension was divided into 2 equal portions which were dispensed into separate sterile, foil-covered flasks and aerated with sterile air. Ten mussels (total weight ca $100 \mathrm{~g}$ ) were added in a sterile net to the test flask; the control flask received a sterile net but no mussels. The flasks were then incubated at $11^{\circ} \mathrm{C}$ and samples $(10 \mathrm{ml})$ of the suspension in each flask were collected at $0,2,20$, and $44 \mathrm{~h}$ and assayed for their content of viable Rs cells on SKDM. At 44 h, a pronounced fluffy sediment $(0.5 \mathrm{~g}$ wet weight; apparently representing mussel feces) had accumulated in the test flask (despite the convection currents set up by the aeration); this material was collected by centrifugation $(12000 \times \mathrm{g}$, $30 \mathrm{~min}, 4^{\circ} \mathrm{C}$ ) and assayed for its content of viable Rs cells on SKDM. In addition, at 44 h, 5 of the mussels in the test flask were assayed for their viable Rs cell content. To obtain this count, the mussels (shells removed) were individually homogenized in sufficient P-S to yield $20 \%$ $(w / v)$ homogenates. The homogenates were immediately serially diluted to avoid toxicity to the Rs cells and then counted on SKDM.

Inactivation of Rs by mussel tissue extracts. In the first of 2 Rs inactivation studies, mantle and digestive gland tissues from 30 mussels were added to, and 
homogenized in, $2.5 \mathrm{ml}$ of sterile saline to provide separate mantle and digestive gland homogenates of ca $63 \%(\mathrm{w} / \mathrm{v})$ each. The homogenates were then centrifuged $\left(20000 \times g, 20 \mathrm{~min}, 4^{\circ} \mathrm{C}\right)$ to remove particulate material and the supernatants were collected. The supernatants were combined with an equal volume of Rs cell suspension. The latter consisted of KDM2-grown Rs cells in saline with a calculated absorbance of 6.4 at $420 \mathrm{~nm}$. A control mixture consisting of the cell suspension mixed with an equal volume of saline was also prepared. The 3 preparations were incubated at $10^{\circ} \mathrm{C}$ and viable Rs cells in samples $(0.5 \mathrm{ml})$ drawn from each of them were enumerated by culture on SKDM at times 0 , 24 , and $48 \mathrm{~h}$. Smears of the 0,24, and $48 \mathrm{~h}$ samples, stained by the Gram method and the IFAT, were also examined to determine whether intact-appearing Rs cells were present. (The $\mathrm{pH}$ of the mantle, digestive tract, and control preparations was 6, 6, and 7, respectively, as determined by $\mathrm{pH}$ indicator paper.)

In the second Rs inactivation study, mantle and digestive gland tissues from 11 mussels were separately homogenized in sufficient sterile P-S to yield equalstrength $(65 \% \mathrm{w} / \mathrm{v})$ tissue homogenates. The homogenates were centrifuged $\left(12000 \times \mathrm{g}, 30 \mathrm{~min}, 4^{\circ} \mathrm{C}\right)$ to produce clarified extracts which were then filter-sterilized by passage through a series of filters of decreasing pore size (the smallest pore size being $0.45 \mu \mathrm{m}$ in diameter). The test extracts were then mixed with an equal volume of Rs cell suspension (Rs cells in sterile P-S at a calculated absorbance of 2.0 at $420 \mathrm{~nm}$ ). The control mixture consisted of equal volumes of P-S and the Rs cell suspension. The 3 mixtures were then incubated at $11^{\circ} \mathrm{C}$ and samples $(0.5 \mathrm{ml})$ of each of them were collected at $0,23,46$, and $70 \mathrm{~h}$ for viable Rs cell determinations. The Rs cell counts were determined on KDM2

\section{RESULTS AND DISCUSSION}

The results of the experiment on uptake and retention indicated that numbers of presumptive Rs cells sufficient to be detected by the Gram-stain technique were picked up by mussels from the seawater during their 20 h exposure to the pathogen. However, because the bacterium was not detected in any of the mantle tissue samples examined, it did not appear to be invasive in mussels. It was consistently detected, however, in the gill and digestive tract preparations for up to $7 \mathrm{~h}$ following removal of the mussels from the Rs-containing seawater. Its presence in the former probably represented gill-surface contamination and its presence in the latter probably resulted from active ingestion of the pathogen. Mantle, gill, and digestive tract preparations were uniformly negative for Rs in all subsequent sampling (i.e. samples taken at $9,11,24,48,72,96$, and
$120 \mathrm{~h}$ ). These results indicated that surface contamination was only a temporary phenomenon and that the pathogen was readily voided from, or more likely destroyed in (see Tables 3 \& 4), the mussel's digestive tract. Because the Gram-stain technique is a relatively insensitive Rs-detection procedure (Evelyn et al. 1981), low numbers of the pathogen may have been harbored in the mussels for somewhat longer than $7 \mathrm{~h}$. Notwithstanding this possibility, the trend towards disappearance of the pathogen from the mussels with time was clear. It therefore seems reasonable to conclude that mussels will not harbor Rs cells indefinitely after they are removed from a source of contamination. Our experiments showed that mussels were capable of removing Rs cells from seawater (Tables 1 \& 2), and could reduce the infectious load carried by the water in netpens on salmon farms. However, the efficiency of the mussels in this process was affected considerably by the experimental design and thus our experiments are indicative only of the mussel's capability, not its efficiency, at clearing Rs cells from seawater netpens. When Rs cells were suspended in seawater unsupplemented with peptone (Table 1), they were rapidly killed by the seawater (ca 89 and $98 \%$ killed within 2 and $24 \mathrm{~h}$, respectively) and the mussel's opportunity to express its ability to clear viable Rs cells from the water was significantly reduced (only ca $1 \%$ cleared in $24 \mathrm{~h}$; Table 1). Under these conditions, the mussel's effect in the clearing process was probably best measured in terms of the shorter time required for the disappearance of Rs (Table 1). When, however, the seawater was made much less lethal for Rs by the addition of peptone (only $56 \%$ loss of Rs viability in 20 h), the mussel was provided with a better opportunity to express its ability to clear the water of Rs (Table 2). Under these conditions, the mussels accounted for a $40.6 \%$ loss of viable Rs cells in $2 \mathrm{~h}$.

Interestingly, extending the observation time beyond $2 \mathrm{~h}$ in the second clearance experiment did not increase the loss of viable Rs cells caused by the mussels, possibly because the Rs cells remaining in suspension at this stage represented a fraction (perhaps unaggregated cells) of the Rs cell population that was comprised of units too small to be filtered effectively from the water. It is known that some mussels utilize bacteria as food (Zobell \& Landon 1937, Zobell \& Feltham 1938) and that this is also likely true of Mytilus edulis (Birbeck \& McHenery 1982, Seiderer et al. 1987). However, the ability of mussels to filter particles from water is known to be a function of the particle size, with particles smaller than $2 \mu \mathrm{m}$ being filtered with difficulty by $M$. edulis (Winter 1978). Non-aggregated Rs cells which measure $0.5 \times 1.0 \mu \mathrm{m}$ would thus not be filtered effectively. However, in netpens where the Rs cells would be expected to occur predominantly 
Table 1. Effect of the blue mussel Mytilus edulis on the numbers of viable Renibacterium salmoninarum (Rs) cells in seawater $(25 \%)$ at $17.6^{\circ} \mathrm{C}$. Beakers contained mussels (ca $100 \mathrm{~g}$ ) or no mussels and $2.0 \mathrm{l}$ each of aerated Rs cell suspension. ND: none detected

\begin{tabular}{|c|c|c|c|c|c|}
\hline \multirow[t]{2}{*}{ Time (h) } & \multicolumn{2}{|c|}{ Mussels present } & \multicolumn{2}{|c|}{ Mussels absent } & \multirow{2}{*}{$\begin{array}{l}\% \text { Loss due } \\
\text { to mussels } \\
(A-B)\end{array}$} \\
\hline & $\mathrm{Rs} \mathrm{ml}^{-1}$ & $\%$ loss $(\mathrm{A})$ & Rs $\mathrm{ml}^{-1}$ & $\%$ loss $(\mathrm{B})$ & \\
\hline 0 & $2.3 \times 10^{8}$ & - & $2.3 \times 10^{8}$ & - & - \\
\hline 2 & $1.0 \times 10^{7}$ & 95.7 & $2.5 \times 10^{7}$ & 89.1 & 6.6 \\
\hline 24 & $2.3 \times 10^{5}$ & 99.0 & $4.9 \times 10^{6}$ & 97.9 & 1.1 \\
\hline 48 & $1.0 \times 10^{5}$ & -100 & $9.2 \times 10^{5}$ & 99.6 & $\sim 0.4$ \\
\hline 72 & $2.2 \times 10^{3}$ & -100 & $5.0 \times 10^{4}$ & -100 & 0 \\
\hline 96 & ND & & $3.6 \times 10^{3}$ & & \\
\hline 120 & ND & & $4.4 \times 10^{2}$ & & \\
\hline 144 & ND & & $3.2 \times 10^{2}$ & & \\
\hline 168 & ND & & $1.2 \times 10^{2}$ & & \\
\hline 192 & ND & & $0.8 \times 10^{1}$ & & \\
\hline 216 & ND & & ND & & \\
\hline
\end{tabular}

Table 2. Effect of the blue mussel Mytilus edulis on the numbers of viable Renibacterium salmoninarum (Rs) cells in seawater (25\%) containing peptone $(0.1 \% \mathrm{w} / \mathrm{v})$ at $11^{\circ} \mathrm{C}$. Flasks contained mussels (ca $\left.100 \mathrm{~g}\right)$ or no mussels and 1.51 of aerated Rs cell suspension

\begin{tabular}{|c|c|c|c|c|c|}
\hline \multirow[t]{2}{*}{ Time (h) } & \multicolumn{2}{|c|}{ Mussels present } & \multicolumn{2}{|c|}{ Mussels absent } & \multirow{2}{*}{$\begin{array}{l}\% \text { Loss due } \\
\text { to mussels } \\
\qquad(A-B)\end{array}$} \\
\hline & Rs $\mathrm{ml}^{-1}$ & $\%$ loss $(\mathrm{A})$ & $\mathrm{Rs} \mathrm{ml} \mathrm{m}^{-1}$ & $\% \operatorname{loss}(\mathrm{B})$ & \\
\hline 0 & $3.2 \times 10^{7}$ & - & $3.2 \times 10^{7}$ & - & - \\
\hline 2 & $1.9 \times 10^{7}$ & 40.6 & $3.3 \times 10^{7}$ & 0 & 40.6 \\
\hline 20 & $1.5 \times 10^{6}$ & 95.3 & $1.4 \times 10^{7}$ & 56.2 & 39.1 \\
\hline $44^{2}$ & $1.1 \times 10^{6}$ & 96.6 & $1.3 \times 10^{7}$ & 59.4 & 37.2 \\
\hline \multicolumn{6}{|c|}{$\begin{array}{l}\text { At this sampling of the mussel-containing flask, the seawater-peptone, } \\
\text { mussels, and mussel feces (sedimented) contained } 3.4,0.4 \text {, and } 6.8 \% \text {, } \\
\text { respectively, of the viable Rs cells added to the flask. This means that } \\
89.6 \% \text { of the Rs cells were killed in this flask }\end{array}$} \\
\hline
\end{tabular}

added to the flask were accounted for. The missing $89.4 \%$ of the Rs cells represented cells killed as a result of ingestion by the mussels ( $40.6 \%$; Table 2 ) and by the action of the suspending medium (48.8\%, i.e. 89.4 less 40.6$)$. We consider that all of the Rs cells ingested were killed in the digestive tract because digestive gland extracts were rapidly lethal for Rs cells (see Tables 3 \& 4). The live Rs cells detected in the sedimented feces were most likely cells removed from the suspending medium by the sedimenting feces. Interestingly, the fraction of the Rs cells killed by the suspending medium in the mussel-con- taining flask (48.8\%) was less than that in the control flask $(59.4 \%)$, perhaps because of the added protection afforded by organic matter released to the suspending medium by the mussels.

The mussels produced substances (probably enzymes) in their digestive glands capable of killing Rs cells (Tables 3 \& 4). When Rs cells were suspended in extracts prepared from digestive gland tissue, there was a drastic drop in the counts of viable Rs cells present relative to the decreases that occurred in the control suspensions or in extracts prepared from nondigestive-gland tissue such as mantle tissue. The lethal effect of the digestive gland extract was particularly impressive in the second experiment

in fecal clumps rather than as single cells, higher uptake efficiencies, perhaps equivalent to (or exceeding) those observed for blue mussels with other bacteria, would be anticipated. With the blue mussel, Birbeck \& McHenery (1982) have reported clearance rates for other (slightly larger) bacteria of about $90 \%$ in $1.93 \mathrm{~h}$.

In the second experiment, a very obvious fecal deposit accumulated in the flask containing the mussels, perhaps an indication that the mussels used in this experiment had been feeding much more actively prior to their removal from Departure Bay than those used in the first clearing experiment (no fecal deposit was noted with mussels in the first experiment). Counts at $44 \mathrm{~h}$ showed the feces to contain $6.8 \%$ of the viable cells added to the flask. At this time, $0.4 \%$ of the added viable cells were associated with the mussels, most likely as surface contaminants. When the viable cells in the feces and on the mussels were added to those remaining in the water column $(3.4 \%), 10.6 \%$ of the viable cells where the suspending medium used in the experiment was P-S, a medium far less bactericidal than the one (saline) that was used in the first tissue extract experiment. The findings with the digestive gland extracts indicated that Rs cells are not likely to survive for long in the digestive tract of the mussel. The substances present in the extract are very likely the ones secreted into the digestive tract to digest ingested food.

Interestingly, considerable numbers of intactappearing Rs cells were evident in the Gram-and IFATstained smears of digestive tract material even when viable Rs cells were no longer detectable (Table 3 ). It appears, therefore, that killing of the Rs cell by the substances in the digestive tract is not necessarily synonymous with lysis of the Rs cell. Thus, the lysozyme-like enzymes that are thought to be active against bacteria in the digestive tract of the mussel (Birbeck \& McHenery 1982) may not be the only bactericidal substance(s) present there. Indeed, resistance of 
Table 3. Effect of Mytilus edulis digestive gland (DG) and mantle (M) tissue extracts on the viability of Renibacterium salmoninarum (Rs) cells suspended in saline $10.85 \% \mathrm{w} / \mathrm{v}$ $\mathrm{NaCl}$ at $10^{\circ} \mathrm{C}$. At all samplings, smears of the 3 reaction mixtures contanned numbers of intact-appearing Rs cells detectable by the Gram-stain and the indirect fluorescence antibody techniques. ND: none detected

\begin{tabular}{|cccc|}
\hline \multirow{2}{*}{ Time $(\mathrm{h})$} & \multicolumn{3}{c|}{ Viable Rs cells $\mathrm{ml}^{-1}$} \\
& DG extract & M extract & Saline (control) \\
\hline 0 & $1 \times 10^{11}$ & $1 \times 10^{11}$ & $1 \times 10^{11}$ \\
24 & $\mathrm{ND}$ & $6 \times 10^{8}$ & $4 \times 10^{7}$ \\
48 & $\mathrm{ND}$ & $2 \times 10^{8}$ & $2 \times 10^{7}$ \\
\hline
\end{tabular}

Table 4. Effect of Mytilus edulis digestive gland (DG) and mantle (M) tissue extracts on the viability of Renibacterium salmoninarum (Rs) cells suspended in peptone $(0.1 \% \mathrm{w} / \mathrm{v})$ saline $(0.85 \% \mathrm{w} / \mathrm{v} \mathrm{NaCl})(\mathrm{P}-\mathrm{S})$ at $11^{\circ} \mathrm{C}$. ND: none detected

\begin{tabular}{|cccc|}
\hline \multirow{2}{*}{ Time (h) } & \multicolumn{3}{c|}{ Viable Rs cells ml ${ }^{-1}$} \\
& DG extract & M extract & P-S (no extract) \\
\hline 0 & $9.5 \times 10^{8}$ & $9.5 \times 10^{8}$ & $9.5 \times 10^{8}$ \\
23 & $1.8 \times 10^{6}$ & $4.6 \times 10^{8}$ & $8.5 \times 10^{8}$ \\
46 & $1.6 \times 10^{4}$ & $9.0 \times 10^{7}$ & $5.2 \times 10^{8}$ \\
70 & ND & $4.0 \times 10^{8}$ & $7.8 \times 10^{8}$ \\
\hline
\end{tabular}

Rs cells to mussel lysozyme would not be surprising because in our laboratory Rs has been shown to resist killing by salmonid egg lysozyme (Evelyn unpubl. data) and because its resistance to lysozyme has already been noted (Fryer \& Sanders 1981). The active bactericidal component in our digestive gland extracts was also obviously different from the lytic agent reported as occurring in the digestive tract of Mytilus edulis by Seiderer et al. (1987) because ours passed through a filter $(0.45 \mu \mathrm{m}$ pore diameter filter) and theirs did not.

To summarize, our experiments indicated that the blue mussel is unlikely to serve as a long-term reservoir of infection with the Rs pathogen on salmon farms. In fact, by virtue of its ability to clear the seawater of Rs cells, the mussel probably reduces the chances of fishto-fish infections in netpens mediated by the waterborne route (e.g. with Rs-infected feces). Finally, the studies confirmed earlier results of Evelyn (1988) showing that seawater is lethal for Rs and, in addition, they showed that this effect is not likely to be completely negated by the presence of organic matter in the water.
Acknowledgements. This research was partly funded by an International Development Research Centre grant to J.O.P. and a Natural Science and Engineering Research Council of Canada operating grant to L.J.A.

\section{LITERATURE CITED}

Austin, B., Embley, T M., Goodfellow, M. (1983). Selective isolation of Renibacterium salmoninarum. FEMS Microbiol. Lett. 17: 111-114

Birbeck, T. H., McHenery, J. G. (1982). Degradation of bacteria by Mytilus edulis. Mar. Biol. 72: 7-12

Brown, R. C., Hopps, H. C. (1973). Staining of bacteria in tissue sections: a reliable Gram stain method. Am. J. Clin. Pathol. 60: 234-240

Bullock, G. L., Stuckey, H. M. (1975). Fluorescent antibody identification and detection of the Corynebacterium causing kidney disease of salmonids. J. Fish. Res. Bd Can. 32: $2224-2227$

Elliott, D. G., Pascho, R. J., Bullock, G. L. (1989). Developments in the control of bacterial kidney disease of salmonid fishes. Dis aquat. Org. 6: 201-215

Evelyn, T P. T. (1971). An improved growth medium for the kidney disease bacterium and some notes on using the medium. Bull. Off. Int. Epiz. 87: 551-513

Evelyn, T P. T (1988). Bacterial kidney disease in British Columbia, Canada: comments on its epizootiology and methods for its control on fish farms. In: AQUA NOR 87 Trondheim International Conference, Norske Fiskeoppdretteres Forening-Fiskeoppdretternes Salgslag $\mathrm{A} / \mathrm{L}$, Trondheim, Norway, p. 51-57

Evelyn, T. P. T., Bell, G. R., Prosperi-Porta, L., Ketcheson, J. E (1989). A simple technique for accelerating the growth of the kidney disease bacterium Renibacterium salmoninarum on a commonly used culture medium (KDM2) Dis. aquat. Org. 7: $231-234$

Evelyn, T. P. T., Ketcheson, J. E., Prosperi-Porta, L. (1981). The clinical significance of immunofluorescence-based diagnoses of the bacterial kidney disease carrier. Fish Pathol. 15: 293-300

Fryer, J. L., Sanders, J. E. (1981). Bacterial kidney disease of salmonid fish. A. Rev. Microbiol. 35: 273- 298

Humason, G. L. (1979). Animal tissue techniques, 4th edn. W. H. Freeman \& Co., San Francisco

Meyers, T. R. (1984). Marine bivalve mollusks as reservoirs of viral finfish pathogens: significance to marine and anadromous finfish culture. Mar. Fish. Rev. 46: 14-17

Seiderer, L. J., Newell, R. C., Schultes, K., Robb, F. T., Turley, C. M. (1987). Novel bacteriolytic activity associated with the style microflora of the mussel Mytilus edulis (L). J. exp. mar. Biol. Ecol. 110: 213-224

Winter, J. E. (1978). A review of the knowledge of suspension feeding in lamellibrachiate bivalves, with special reference to artificial aquaculture systems. Aquaculture 13: $1-33$

Zobell, C. E., Feltham, C. B. (1938). Bacteria as food for certain marine invertebrates. J. mar. Res. 1: 312-327

Zobell, C. E., Landon, W. A. (1937). Bacterial nutrition of the California mussel. Proc. Soc exp. Biol. Med. 36: 607-609

Manuscript first received: November 5, 1992

Revised version accepted: November 12, 1993 